ISSN 1678-3921

Journal homepage: www.embrapa.br/pab

For manuscript submission and journal contents, access: www.scielo.br/pab
Hernán Antonio Alzate Díaz ${ }^{(1 凶)}$ (iD, Adriana Patricia Muñoz Ramírez(2) (D), Maurício Gustavo Coelho

Emerenciano ${ }^{(3)}$ (iD and

Sandra Clemencia Pardo Carrasco(1) (iD)

(1) Universidad Nacional de Colombia Sede Medellín, Departamento de Producción Animal, Facultad de Ciencias Agrarias, Carrera 65, \#59A-110 Bloque 50, Oficina 309 Núcleo El Volador, Medellín, Colombia. E-mail: haalzate@unal.edu.co, scpardoc@unal.edu.co

(2) Universidad Nacional de Colombia Sede Bogotá, Departamento de Producción Animal, Facultad de Medicina Veterinaria y de Zootecnia, Carrera 30, \#45-03 Edificio 561, Oficina 5, Bogota, Colombia.

E-mail: apmonzr@unal.edu.co

(3) Universidade do Estado de Santa Catarina, Departamento de Engenharia de Pesca, Centro de Educação Superior da Região Sul, Laboratório de Aquicultura, Rua Coronel Fernandes Martins, no 270, Progresso, CEP 88790-000 Laguna, SC, Brazil.

E-mail: mauricio.emerenciano@udesc.br

${ }^{凶}$ Corresponding author

Received

February 02, 2020

Accepted

November 11, 2020

How to cite

ALZATE-DÍAZ, H.A.; MUÑOZ-RAMÍREZ, A.P.; EMERENCIANO, M.G.C.; PARDOCARRASCO, S.C. Organoleptic and nutritional characteristics of fillets of pirapitinga fed different protein sources in a biofloc system. Pesquisa Agropecuária Brasileira, v.55, e01795, 2020. DOI: https://doi.org/10.1590/ S1678-3921.pab2020.v55.01795.

\section{Organoleptic and nutritional characteristics of fillets of pirapitinga fed different protein sources in a biofloc system}

\begin{abstract}
The objective of this work was to assess the organoleptic and nutritional quality of fillets of cultured pirapitinga (Piaractus brachypomus), fed diets with either partial or total substitution of fishmeal, and to determine the nutritional quality of the biofloc meal. Fish were cultured in $500-\mathrm{L}$ tanks with 84 fish $\mathrm{m}^{-3}$, treated with biofloc technology (BFT), and fed three isoproteic diets (24\% crude protein, CP) formulated with the following protein sources: soybean meal (SM); soybean meal + fishmeal (SM+FM); and soybean meal + spirulina $(\mathrm{SM}+\mathrm{SP})$. After 84 days of culture, microbiological, nutritional, and sensory analyses were carried out on fillets with skin and without scales. There were not significant differences for dry matter, CP, moisture, and fat content between treatments. The fatty acid profile showed $21.3 \pm 1.03 \%$ polyunsaturated fatty acids (PUFAs $=\omega-3+\omega-6), 37.11 \pm 1.29 \%$ monounsaturated fatty acids (MUFAs), and $41.58 \pm 1.34 \%$ saturated fatty acids (SFAs). The protein sources soybean meal and spirulina do not affect the fillet quality of pirapitinga nor the nutritional quality of biofloc meal.
\end{abstract}

Index terms: Piaractus brachypomus, BFT, fatty acid, fillet quality, soybean meal, spirulin.

\section{Características organolépticas e nutricionais de filés de pirapitinga alimentada com diferentes fontes de proteína em sistema de bioflocos}

Resumo - O objetivo deste trabalho foi avaliar a qualidade organoléptica e nutricional de filés de pirapitinga (Piaractus brachypomus) cultivada, alimantada com dietas com substituição parcial ou total da farinha de peixe, e determinar a qualidade nutricional da farinha de bioflocos. Os peixes foram cultivados em tanques de $500 \mathrm{~L}$ com 84 peixes $\mathrm{m}^{-3}$, em tecnologia de bioflocos (BFT), e alimentados com três dietas isoproteicas (24\% proteína bruta, PB) formuladas com as seguintes fontes proteicas: farelo de soja (SM); farelo de soja + farinha de peixe (SM + FPM); e farelo de soja + espirulina (SM + SP). Após 84 dias de cultivo, foram realizadas análises microbiológicas, nutricionais e sensoriais dos filés com pele e sem escamas. Não houve diferenças significativas quanto a matéria seca, $\mathrm{PB}$, umidade e teor de gordura entre os tratamentos avaliados. O perfil de ácidos graxos foi $21,3 \pm 1,03 \%$ de ácidos graxos poli-insaturados (PUFAs $=\omega-3+\omega-6), 37,11 \pm 1,29 \%$ de ácidos graxos monoinsaturados (MUFAs) e 41,58 $\pm 1,34 \%$ de ácidos graxos saturados (SFAs). As fontes de proteína farelo de soja e spirulina não afetam a qualidade do filé de pirapitinga nem a qualidade nutricional da farinha de bioflocos.

Termos para indexação: Piaractus brachypomus, BFT, ácidos graxos, qualidade do filé, farelo de soja, spirulina. 


\section{Introduction}

Fish consumption in the world has grown at 5.3\% per year and has reached a consumption of $20.5 \mathrm{~kg}$ per capita year in 2018 (FAO, 2020). In 2018 also, 178.5 million tonnes of fish produced by aquaculture and fisheries were consumed, and 22.2 million tonnes were destined to other uses such as fishmeal and fish oil production.

In continental aquaculture, species such as pirapitinga [Piaractus brachypomus Cuvier, 181 (Serrasalmidae)] are very important for nutrition in countries such as Colombia, Venezuela, and Brazil (García et al., 2013). In Colombia, the average annual growth of fish production has been $12 \%$, and pirapitinga occupies the second place in production (Cruz-Casallas et al., 2011) due to its resistance, good flesh quality, and good flavor (Suárez Mahecha et al., 2008).

Over the years, aquaculture has been intensifying production systems with a more sustainable approach in both environmental and economic aspects (Avnimelech, 2009). Species such as tilapia Oreochromis niloticus, shrimp (Emerenciano et al., 2014), and also pirapitinga have been produced in more intensive systems like the biofloc technology (BFT), in order to improve their competitiveness and productivity, as well as to allow of a better use of space and water (Chaverra Garcés, 2016). These favorable characteristics of the BFT system have led many producers to use this technology.

Fishmeal has been the most important source of protein in aquaculture feed and, due to its scarcity and cost, the sector is trying to reduce or eliminate its use, to obtain a greater sustainability (Biswas et al., 2017). The use of plant origin proteins and oils either partial or total substitution of fishmeal in aquafeeds has been investigated by different authors, for various aquatic species. Among these meal, soybean has a very complete amino acid profile (Hardy, 2010), as well as spirulina seaweed Arthrospira platensis, which has appropriate protein and fatty acid contents (Habib et al., 2008).

Regarding the species produced in BFT, there are few studies on the nutritional composition of fish (Castro González et al., 2013), their sensory attributes, and the nutritional composition of biofloc meal that can generate nutritional effects in situ (Emerenciano et al., 2014).
The objective of this work was to assess the organoleptic and nutritional quality of fillets of cultured pirapitinga, fed diets with either partial or total substitution of fishmeal, and to determine the nutritional quality of the biofloc meal.

\section{Materials and Methods}

The study was carried out in the Laboratorio de Modelación Animal (Lama) of the Universidad Nacional de Colombia, Sede Medellín, Colombia (6 $15^{\prime} 44^{\prime \prime} \mathrm{N}, 75^{\circ} 344^{\prime} 37^{\prime \prime} \mathrm{W}$, at $1,600 \mathrm{~m}$ altitude), with $26^{\circ} \mathrm{C}$ average environmental temperature and $65 \%$ relative humidity.

Nine round, plastic tanks of $500 \mathrm{~L}$ (450 L useful volume), under cover with mesh (80\%), with individual heaters (300 watts/ 500 L Resun, Shenzhen, China) were used as experimental units. The aeration of the tanks was performed using an $\mathrm{HG}-\mathrm{C} / \mathrm{C} 2,1 / 4$ HP pump (Pump Power, USA), to which a system of microperforated air diffuser hoses $(120 \mathrm{~cm}$ circles/ tank) was attached from the bottom of the tank, in order to favor the resuspension of the particles.

Juveniles of Piaractus brachypomus with average weight of $0.1 \pm 0.01 \mathrm{~g}$ were obtained from a commercial laboratory. Fish were stocked in a 1,000 L tank and fed to apparent satiety with a commercial food containing $38 \%$ crude protein (CP) (extruded feed, Solla SA, Colombia), until they reached $55.6 \pm 9.6 \mathrm{~g}$ average weight. From that point on, fish were randomly stocked in nine experimental units, in three tanks per treatment, and 42 fish per tank. The experimental period corresponded to 84 days, until fish reached $200 \pm 30$ g average weight.

During the experiment, the water quality remained within acceptable ranges for the species, as follows: dissolved oxygen (DO) from 5.1 to $5.3 \mathrm{mg} \mathrm{L}^{-1}$, and $\mathrm{pH}$ from 7.0 to 7.2, both registered with the water quality monitor YSI Professional Plus (Yellow Springs, OH, USA); nitrogen compounds from 0.1 to $0.2 \mathrm{mg} \mathrm{L}^{-1}, 0.4$ to $0.5 \mathrm{mg} \mathrm{L}^{-1}$, and 184 to $209 \mathrm{mg} \mathrm{L}^{-1}$, which correspond to ammonium, nitrite, and nitrate, respectively, which were determined using the Genesys 105 UVVIS spectrophotometer (Thermo Fisher Scientific, Waltham, MA, USA).

The biofloc preparation was carried out following the methodology described by Chaverra Garcés (2016). It started with red Californian earth worm Eisenia 
foetida leachate at a rate of $1 \mathrm{~L}$ per tank. The units were left for 20 days in maturation with aeration and permanent water heating. During this time, molasses at $0.02 \mathrm{~g} \mathrm{~L}^{-1}$ as a carbon source, $5 \mathrm{mg} \mathrm{L}^{-1}$ ammonium chloride $\left(\mathrm{NH}_{4} \mathrm{Cl}\right), 50 \mathrm{mg} \mathrm{L}^{-1}$ sodium bicarbonate $\left(\mathrm{NaHCO}_{3}\right)$, and $2 \mathrm{~g} \mathrm{~L}^{-1}$ sea salt at were daily added to water. A C:N ratio of 15:1 was maintained to favor the heterotrophic bacterial culture (Emerenciano et al., 2017). At the end of the 84 days of culture, the fatty acid and amino acid composition of a biofloc pool was determined in each treatment (sample of $\sim 30 \mathrm{~g}$ total weight). For the collection of the biofloc samples, contents from each tank were filtered with a $45 \mu \mathrm{m}$ mesh and dehydrated by lyophilization for 48 hours. Later, they were vacuum packed and sent for analysis. Because there is only one result per treatment, no statistical analysis was carried out.

Three isoproteic extruded diets with $24 \%$ CP were processed in the Laboratorio de Nutrición Acuícola. The formula and proximal composition of the experimental diets and protein sources are described (Tables 1 and 2). Diets were provided to apparent satiety. The treatments used were protein-based diets formulated with soybean meal (SM); soybean meal + fish meal $(\mathrm{SM}+\mathrm{FM})$ with $5 \%$ replacement of the soybean meal; and soybean meal $+\operatorname{spirulin}(\mathrm{SM}+\mathrm{SP})$ with $5 \%$ replacement of the soybean meal.

The fish for the samples were sacrificed by thermal shock in water at $6^{\circ} \mathrm{C}$ and up to the total loss of the swimming axis (Gregory \& Wotton, 1986) and subsequent spinal cutting. A total of 20 fish was taken from each tank, and fillet samples with skin and without scales were obtained, as this is the way pirapitinga is consumed in Colombia.

The microbiological evaluation was carried out in the Laboratorio de Microbiología de Aguas y Alimentos. A sample of $25 \mathrm{~g}$ of fillet was taken from each tank, maintaining the cold chain and the aseptic conditions (Gregory \& Wotton, 1986). Analyses of total coliforms, fecal coliforms, Salmonella sp. and Staphylococcus aureus were performed by the positive coagulase method; all the procedures met the 15214 Standard (ISO, 1998).

The proximal analysis was carried out in the Laboratorio de Análisis Químico y Bromatológico. Samples of 20 to $25 \mathrm{~g}$ of fillet were taken from each tank, transported under refrigeration and, then, subjected to oven drying and fine grinding in the laboratory. The methods used are ISO/IEC:2005, accredited by the national organization of accreditation (ONAC).

The amino acid evaluation was carried out in the Instrumental Analysis Laboratory. A sample of $50 \mathrm{~g}$

Table 1. Formula (g $100 \mathrm{~g}^{-1}$ of diet) and proximal composition of the experimental diets used to feed pirapitinga (Piaractus brachypomus) in the biofloc system.

\begin{tabular}{lccc}
\hline Ingredient & $\begin{array}{c}\text { Soybean } \\
\text { meal }\end{array}$ & $\begin{array}{c}\text { Soybean } \\
\text { meal + Fish } \\
\text { meal }\end{array}$ & $\begin{array}{c}\text { Soybean } \\
\text { meal + } \\
\text { spirulina }\end{array}$ \\
\hline Crystal rice & 15 & 15 & 15 \\
Wheat flour & 15 & 15 & 15 \\
Rice flour 7\% & 2.42 & 6.20 & 5.64 \\
Soybean meal 47\% & 32.93 & 25.62 & 25.40 \\
Extruded soybean & 5 & 5 & 5 \\
Soy oil & 1 & 1 & 1 \\
Calcium carbonate & 4.37 & 3.65 & 3.69 \\
Tricalfos (tricalcium phosphate) & 2.72 & 2.40 & 3.09 \\
Salt & 0.77 & 0.41 & 0.30 \\
Premix Vitamin & 0.30 & 0.27 & 0.30 \\
L-methionine & 0.23 & 0.21 & 0.22 \\
L-lysine Hcl & 0.14 & 0.08 & 0.21 \\
Choline chloride 60\% & 0.06 & 0.060 & 0.06 \\
L-threonine & 0.05 & 0.04 & 0.03 \\
Antioxidants & 0.02 & 0.02 & 0.02 \\
Fish meal & 0 & 5 & 0 \\
Spirulina & 0.43 & 0 & 5 \\
\hline Proximal composition & 100 & 100 & 100 \\
\hline Moisture (\%) & 24.4 & 6.3 & 5 \\
Crude protein (\%) & 25 & 25 \\
Ashes (\%) & 3993 & 11.05 & 11.45 \\
Ether extract (\%) & 2.48 & 2.65 \\
Crude fiber (\%) & 5.45 & 4.5 \\
Gross energy Cal/G & & & 4134 \\
\hline Diet cost (US\$ kg-1) & 0.66 \\
\hline & 0.45 & \\
\hline
\end{tabular}

Table 2. Proximal composition of protein sources used in the experimental diets (as feed percentage) used to feed pirapitinga (Piaractus brachypomus) in the biofloc system.

\begin{tabular}{|c|c|c|c|}
\hline \multirow{2}{*}{$\begin{array}{l}\text { Proximal } \\
\text { composition }\end{array}$} & \multirow[t]{2}{*}{ Spirulina $^{(1)}$} & Fish & Soybean meal \\
\hline & & Meal $^{(1)}$ & $(\mathrm{NRC}, 2012)^{(1)}$ \\
\hline Moisture (\%) & 6.1 & 7.2 & 12.0 \\
\hline Crude Protein (\%) & 61.3 & 60.0 & 47.7 \\
\hline Ashes $(\%)$ & 11.4 & 26.7 & 6.3 \\
\hline Ether extract (\%) & 0.5 & 5.3 & 1.5 \\
\hline Crude fiber $(\%)$ & 2.8 & 0.6 & 3.9 \\
\hline Gross energy $(\mathrm{Cal} / \mathrm{G})$ & 4754 & 3781 & 4256 \\
\hline Phosphorus (\%) & 1.2 & 4.1 & 0.6 \\
\hline
\end{tabular}

(1)NRC, National Research Council. (2012). 
of tissue (fillet pool of at least 4 fish) was taken from each experimental unit. The samples were prepared by cutting pieces of approximately $1 \mathrm{~cm}$ width, and then taken to an industrial refrigerator at a temperature between $-18^{\circ} \mathrm{C}$ and $-21^{\circ} \mathrm{C}$. Afterward, they were lyophilized at $-40^{\circ} \mathrm{C}$ for 48 hours, weighed again and packed in vacuum. For the analysis, acid hydrolysis was carried out using the 994-12 test method (Cunniff, 1997), and a subsequent analysis by the high-performance liquid chromatography (HPLC) model 1100 series (Agilent HPLC, CA, USA) with UV/ VIS detector was also carried out. Then, $5 \mu \mathrm{L}$ injection volume with $2 \mathrm{~mL}$ per min flow, with a mobile phase in sodium monophosphate buffer solution, $\mathrm{pH} 7.8$, and $45 \%$ acetonitrile, $45 \%$ methanol, and $45 \%$ water solution were used. The column Agilent-Zorbax Eclipse AAA Analytical 4.6 x 150 mm, $5 \mu \mathrm{m}$ (Restrepo et al., 2012) was used.

The fatty acid profile was carried out in the Laboratorio de Toxicología of the Facultad de Medicina Veterinaria y Zootecnia. The tissue samples were prepared by taking $5 \mathrm{~g}$ of fillet in pool from each tank. For the lyophilization, pieces of $1 \mathrm{~cm}$ width were cut, weighed, and lyophilized, for 48 hours at $-40^{\circ} \mathrm{C}$; later, they were weighed again and vacuum packed. The fatty acid composition analysis was carried out in a Shimadzu GC-20A gas chromatograph (Shimadzu Scientific, Tokyo, Japan), with automatic injector and flame ionization detector, using a Folch modified methodology (Restrepo et al., 2012).

The sensory assessment was carried out by taking into account the 4121 standard (ISO, 2003), and the characteristics were evaluated by means of a quantitative, descriptive sensory test by a panel of 5 trained experts from the research organization Fundación Instituto Ciencia y Tecnología Alimentaria (Intal, Colombia). Fresh cuts, parallel to each other at $3 \mathrm{~mm}$ distance, and perpendicular to the lateral line in the anterior-caudal direction, were made for each fresh fillet, on its internal side, keeping the skin intact to provide stability (Suárez Mahecha et al., 2008). For each experimental unit, $250 \mathrm{~g}$ of fresh fillet, steam cooked and wrapped in aluminum foil at an internal temperature of approximately $70^{\circ} \mathrm{C}$ for $3 \mathrm{~min}$ were used. The sensory test was quantitative, descriptive with descriptors of intensity corresponding to the following: characteristic and objectionable odor in raw samples, and appearance, characteristic, and objectionable flavor, cohesiveness, oiliness, in cooked product, sensory quality, and acceptance, all in a scale of intensity from 0 to 10 , where 0 represents the absence of the characteristic, and values from 9 to 10 represent a very marked characteristic in the fillet (Suárez Mahecha et al., 2008).

The compliance of normality (Shapiro-Wilk's and Kolmogorov-Smirnov's tests) and the homogeneity of variances were verified with the Bartletts' test for the characteristics evaluated in the fillet. A one-way analysis of variance was carried out to determine the effect of the treatment on the fillet characteristics through the Proc GLM procedure. Since the significant effect of the treatment at 5\% probability is known, the means were subjected to the Tukey's test to identify the differences among the treatments. All procedures were performed with the statistical software SAS System (SAS Institute Inc., Cary, NC, USA). The sensory analyses of the fillets were carried out through a quantitative, descriptive test with descriptors of intensity of the fish flesh.

\section{Results and Discussion}

At the end of the 84 days of fish culture, biomasses between 15.3 and $16.8 \mathrm{~kg} \mathrm{~m}^{-3}$, with $100 \%$ survival for all treatments were found. The pirapitingas final weights were $203.8 \pm 25.9 \mathrm{~g}, 223.3 \pm 10.9 \mathrm{~g}$, and $196.9 \pm 21.7 \mathrm{~g}$, for the treatments $\mathrm{SM}, \mathrm{SM}+\mathrm{FM}$, and $\mathrm{SM}+\mathrm{SP}$, respectively. Chaverra Garcés et al. (2017) reported GDP of 0.43 to $0.5 \mathrm{~g}$ per day with the use of plant-based diets, with soybean cake as a protein source for pirapitinga; this value is lower than that calculated for the present study, which is $1.7 \pm 0.1 \mathrm{~g}$ per day.

The microbiological analyses found adequate ranges for consumption in the tests of total coliforms and total absence of fecal coliforms. Regarding the concentration of coagulase-positive Staphylococcus aureus, concentrations $<100 \mathrm{CFU} \mathrm{g}^{-1}$ were found, and the absence of Salmonella spp. was reported. The results showed that the flesh of pirapitinga fed with the experimental diets and obtained from the biofloc culture is apt for consumption, according to the 15214 standard (ISO, 1998).

The acceptance of pirapitinga flesh was $100 \%$ in each of the cases evaluated by the panel of experts, and there were no statistical difference among treatments (Table 3). Barrero et al. (2012) performed 
sensory analysis by hedonic test on a scale from 1 to 9 for Piaractus brachypomus cultured in biofloc. Also, Suárez Mahecha et al. (2008) conducted a similar test for preserved fillets of hybrid cachama. The findings by the authors, as well as the ones in the present study, point out that the sensory quality of the fillets cultured in biofloc is competitive in characteristics such as characteristic odor and flavor, as well as in their appearance.

No significant differences among treatments were found in the proximal analysis of pirapitinga fillets (Table 4). In studies on pirapitinga fillets, García et al. (2013) reported $17.12 \%$ crude protein and $75.30 \%$ moisture. For the same species, Barrero et al. (2012) found similar values for crude protein $(19.3 \pm 0.3 \%)$ and moisture $(76.5 \pm 0.3 \%)$. The fat content in fish flesh tends to be lower than in other meats; however, it is usually very variable and is classified as lean or white when the fat content is $<3 \%$, as semi-fat if its content is between $3-5 \%$, and as fatty fillet when its content is $>5 \%$ (Aquerreta et al., 2001). Thus, the pirapitinga fillets with skin of the present study, with fat content between $2.2 \pm 0.8$ and $2.6 \pm 1.0 \%$, can be classified as lean. It should be noted that the fat of this species has characteristics of great relevance because it has omega-3 type fatty acids and low cholesterol content (Aquerreta et al., 2001; Acuña Reyes, 2013).

Table 3. Sensory quality attributes of pirapitinga (Piaractus brachypomus) fillets, by means of descriptive intensity tests $^{(1)}$.

\begin{tabular}{llccc}
\hline $\begin{array}{l}\text { Sensory } \\
\text { quality }\end{array}$ & Descriptor & \multicolumn{3}{c}{ Treatments } \\
\cline { 3 - 5 } Fresh & $\begin{array}{c}\text { Soybean } \\
\text { meal (SM) }\end{array}$ & $\begin{array}{c}\text { SM + fish } \\
\text { meal }\end{array}$ & $\begin{array}{c}\text { SM + } \\
\text { spirulina }\end{array}$ \\
\hline & $\begin{array}{l}\text { Characteristic ap- } \\
\text { pearance }\end{array}$ & $8.1 \pm 0.3$ & $8.5 \pm 0.7$ & $7.9 \pm 1.0$ \\
& Characteristic odor & $7.6 \pm 0.4$ & $8.1 \pm 0.7$ & $7.8 \pm 0.2$ \\
& Objectionable odor & $0.3 \pm 0.2$ & $0.1 \pm 0.1$ & $0.3 \pm 0.2$ \\
\hline \multirow{4}{*}{ Cooked } & Characteristic odor & $7.5 \pm 0.4$ & $8.0 \pm 0.2$ & $7.6 \pm 0.5$ \\
& Characteristic flavor & $8.0 \pm 0.2$ & $7.9 \pm 0.3$ & $7.6 \pm 0.2$ \\
& Objectionable flavor & $0.3 \pm 0.2$ & $0.3 \pm 0.2$ & $0.2 \pm 0.2$ \\
& Cohesiveness & $2.1 \pm 0.2$ & $2 \pm 0.1$ & $1.8 \pm 0.2$ \\
& Oiliness & $2.6 \pm 0.2$ & $2.5 \pm 0.3$ & $2.2 \pm 0.2$ \\
\hline \multirow{2}{*}{} & Sensory quality ${ }^{(2)}$ & $7.9 \pm 0.5$ & $7.8 \pm 0.3$ & $7.3 \pm 0.4$ \\
\cline { 2 - 5 } & Acceptance $(\%)^{(3)}$ & 100 & 100 & 100 \\
\hline
\end{tabular}

${ }^{(1)}$ Data correspond to the mean of three replicates \pm standard deviation. (2) The sensory quality is a mean of the sum of the sensory characteristics in fresh and cooked evaluated fish. ${ }^{(3)}$ Acceptance is a characteristic that evaluates the total consumption of the sample, in percentage, by the panel of experts.
Izquierdo Córser et al. (2000) analyzed black cachama Colossoma macropomum fillets and found $159 \mathrm{mg}$ phosphorus contents and $10 \mathrm{mg}$ calcium contents, with $0.06 \mathrm{Ca}$ : $\mathrm{P}$ ratio in $100 \mathrm{~g}$ of fillet. In the present work, the average $\mathrm{P}$ contents are 200 $\mathrm{mg} 100 \mathrm{~g}^{-1}$, and 27 to $30 \mathrm{mg} 100 \mathrm{~g}^{-1} \mathrm{Ca}$ with $0.14 \mathrm{Ca}$ : $P$ ratio. It should be noted that intermuscular spines, which were not removed for the analyses, are a source of minerals, which could explain the $\mathrm{Ca}$ and $\mathrm{P}$ contents.

The amino acid content showed no significant difference among the treatments (Table 5), which indicates that the addition of fishmeal or spirulina powder did not have any effect on the expression of amino acids in the pirapitinga fillet. Probably, the constant supply of amino acids by bioflocs and the low level of inclusion of these raw materials were not enough to modify the amino acid profile, which can be attributed to a low-cost formulation. High percentages of lysine and low percentages of methionine were observed in the fillets of the present study. These amino acids are responsible for the protein deposition in the muscles (Acuña Reyes, 2013). Very similar lysine contents to those reported in the present work were found for pirapitinga with $10.8 \%$ concentrations in $100 \mathrm{~g}$ of fillet, with higher concentrations of methionine $(8.2 \%)$ and higher content of threonine (15.2\%) and leucine (16.2\%) than the ones reported in the present study (Izquierdo Córser et al., 2000). Another amino acid that had a high level in the present study was leucine, that is responsible for the regulation of glucose in the body (Acuña Reyes, 2013). Lysine contents at reported $7.21 \%$ and methionine contents at $2.47 \%$ for Piaractus

Table 4. Proximal analysis of pirapitinga (Piaractus brachypomus) fillets (g $100 \mathrm{~g}^{-1}$ of fresh fillet) cultured in a biofloc system with three protein sources ${ }^{(1)}$.

\begin{tabular}{|c|c|c|c|}
\hline \multirow[t]{2}{*}{ Parameter } & \multicolumn{3}{|c|}{ Treatments } \\
\hline & $\begin{array}{c}\text { Soybean } \\
\text { meal }\end{array}$ & $\begin{array}{c}\text { Soybean meal } \\
+ \text { fish meal }\end{array}$ & $\begin{array}{c}\text { Soybean meal } \\
+ \text { spirulina }\end{array}$ \\
\hline Crude protein (\%) & $18.9 \pm 0.7$ & $18.5 \pm 0.7$ & $18.3 \pm 0.7$ \\
\hline Moisture (\%) & $74.6 \pm 0.5$ & $75.9 \pm 0.9$ & $74.9 \pm 0.5$ \\
\hline Ashes (\%) & $1.2 \pm 0.0$ & $1.2 \pm 0.0$ & $1.2 \pm 0.1$ \\
\hline Ether extract (\%) & $2.6 \pm 1.0$ & $2.2 \pm 0.8$ & $2.5 \pm 1.1$ \\
\hline Calcium (ppm) & $270.7 \pm 12.5$ & $305.0 \pm 50.3$ & $280.0 \pm 21.4$ \\
\hline Phosphorus (\%) & $0.2 \pm 0.0$ & $0.2 \pm 0.0$ & $0.2 \pm 0.0$ \\
\hline
\end{tabular}

(1)Data correspond to the average of three replicates \pm standard deviation. Final average weight $=$ average fish weight after 84 days of culture. 
Table 5. Amino acid in fillets ( $\mathrm{g} 100 \mathrm{~g}^{-1}$ of fillet), expressed as protein percentage, and fatty acid profile (as percentage of total fatty acids detected) of pirapitinga (Piaractus brachypomus) cultured in biofloc systems fed with different protein sources ${ }^{(1)}$.

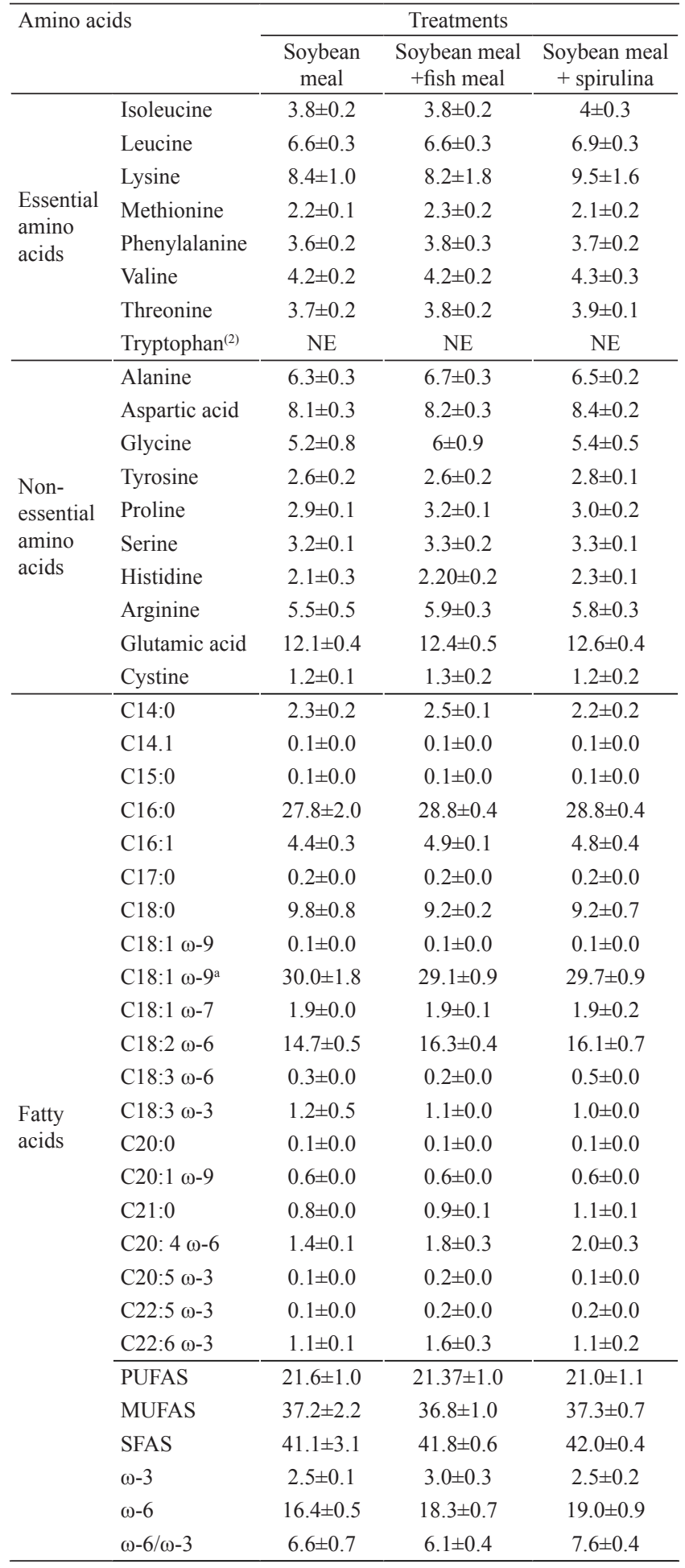

${ }^{(1)}$ Data correspond to the average of three replicates \pm standard deviation. ${ }^{(2)} \mathrm{NE}$, tryptophan was not evaluated in the amino acid analysis. brachypomus, as well as high concentrations of leucine and argyrene were reported by Vásquez Torres (2004). In addition, high levels of glutamic acid, which is of great importance for the human body, since it acts as a neurotransmitter in the central nervous system (Acuña Reyes, 2013), were present in the nonessential amino acids; high values of aspartic acid and alanine, and very low values of cystine were also found.

In general, the SFAs content was higher, followed by the MUFAs and finally the PUFAs, in which the $\omega-6$ content prevailed. The analysis of fatty acids showed elaidic acid as the main MUFA. In the case of PUFAs, the linoleic acid was the most representative, and, in the case of SFAs, the palmitic acid was the most representative. These results corroborate those by Castro González et al. (2013). Saturated fatty acids SFAs between 40 and 42\%, MUFAs between 40 and 44\%, and PUFAs between 15 and $17 \%$ for pirapitinga in traditional system were reported by Céspedes Zambrano \& López Vargas (2015). Similarly, Barrero et al. (2012) studied the fatty acid profile of $P$. brachypomus cultivated in biofloc and RAS. They found the presence of SFAs and MUFAs in adequate amounts for the two systems; however regarding the PUFAs, the treatment with biofloc showed neither the fatty acids 22:2 ( $\omega-6)$ nor the eicosatrienoic acid 20:3 $(\omega-9)$, but it presented 4.4\% DHA amounts and 3.2\% EPA. The $\omega-6: \omega-3$ ratio was higher in the biofloc system than in the RAS one. Thus, it is evident that the microbial diversity of the BFT system certainly influences the flesh quality of organisms in these systems (Emerenciano et al., 2014; Martínez-Córdova et al., 2015).

The content of ethereal extract in the biofloc is commonly within 1 to $15 \%$ range, with considerable contents of PUFAs (Hargreaves, 2013). Azim \& Little (2008) reported 3\% lipids and 27\% PUFAs contents in dry base in biofloc, which is very similar to those found in our study, possibly due to similar conditions such as salinity and food for omnivore species with low concentrations of crude protein. Regarding the biofloc fatty acid profile where pirapitingas were cultured in this study, it is important to highlight the absence of fatty acids such as the $\omega-3$, DPA, DHA, and EPA type, with the notable presence of linolenic acid. In general, a greater percentage of MUFAs was obtained, followed by SFAs and, finally, the 
polyunsaturated fatty acids. The absence of $\omega-3$ fatty acids could be due to the dark conditions and the $\mathrm{C}: \mathrm{N}$ 15:1 ratio used (Martínez-Córdova et al., 2015). The absence of fatty acids such as DHA and others with more than 20 carbons and $\omega-3$ type can be attributed to their concentrations, which are virtually zero, in terrestrial vegetables such as seeds and fruits of oil plants (used in the preparation of diets), (Swanson et al., 2012). Similarly, pirapitinga showed no ability to elongate and desaturate fatty acids significantly, neither in the BTF system studied, nor in the evaluated diets.

No difference was found between treatments for amino acid and fatty acid profile of the biofloc (Table 6). This can be explained, in part, by the raw materials used in the system. One of the compositional characteristics of the biofloc is its protein value, which can be widely variable with crude protein (CP) levels ranging from 10 to $54 \% \mathrm{CP}$ (Castro et al., 2021). An improvement in growth has been shown in animals, associated with the greater total supply of proteins in the crop by the food and the floc consumed (Cardona et al., 2016). The presence of several of the essential amino acids in flocs makes it possible to hypothesize a supplementary feeding of amino acids, when individuals are reared in biofloc (Castro et al., 2021). It has been shown that there is a consumption of the cultivated animal and a significant nutritional contribution of the biofloc, either directly with the culture water or through the use of floc flour for the production of balanced feeds (Emerenciano et al., 2017). Certainly, more studies should be carried out, in order to clarify the factors that modify the relationship of the amino acid profile in BFT.

\section{Conclusions}

1. Different protein sources as from soybean meal or spirulina have no effect on the composition of pirapitinga (Piaractus brachypomus) fillets grown in the biofloc system.

2. The fillets of pirapitinga grown in biofloc technology show microbiological, organoleptic, and sensory characteristics acceptable for human consumption.

3. The biofloc is a food source or supplement for fish.
Table 6. Amino acid and fatty acid content of biofloc samples from the pirapitinga (Piaractus brachypomus) culture (reported as percentage of total fatty acids detected).

\begin{tabular}{|c|c|c|c|}
\hline \multirow[t]{2}{*}{ Amino acids } & \multicolumn{3}{|c|}{ Biofloc biomass } \\
\hline & $\begin{array}{c}\text { Soybean } \\
\text { meal }\end{array}$ & $\begin{array}{c}\text { Soybean meal + } \\
\text { fish meal }\end{array}$ & $\begin{array}{c}\text { Soybean meal }+ \\
\text { spirulina }\end{array}$ \\
\hline Aspartic acid & 1.98 & 1.97 & 2.17 \\
\hline Threonine & 1.09 & 1.07 & 1.20 \\
\hline Serine & 0.85 & 0.85 & 0.94 \\
\hline Glutamic acid & 2.11 & 2.04 & 2.23 \\
\hline Proline & 0.63 & 0.69 & 0.75 \\
\hline Glycine & 1.26 & 1.21 & 1.32 \\
\hline Alanine & 1.45 & 1.40 & 1.58 \\
\hline Valine & 1.22 & 1.11 & 1.25 \\
\hline Isoleucine & 0.86 & 0.76 & 0.86 \\
\hline Leucine & 1.43 & 1.32 & 1.52 \\
\hline Tyrosine & 0.74 & 0.68 & 0.78 \\
\hline Phenylalanine & 1.00 & 0.89 & 1.00 \\
\hline Lysine & 1.02 & 0.68 & 0.95 \\
\hline Histidine & 0.32 & 0.25 & 0.33 \\
\hline Arginine & 1.31 & 1.25 & 1.41 \\
\hline \multicolumn{4}{|l|}{ Fatty acids } \\
\hline C14:0 & 4.15 & 2.81 & 2.19 \\
\hline C14.1 & 2.08 & 1.31 & 1.5 \\
\hline C15:0 & 1.45 & 0.89 & 0.69 \\
\hline C16:0 & 21.65 & 25.12 & 25.93 \\
\hline C16:1 & 8.01 & 8.3 & 5.69 \\
\hline C17:0 & 0 & 0 & 0 \\
\hline C18:0 & 6.45 & 7.66 & 9.72 \\
\hline $\mathrm{C} 18: 1 \omega-9$ & 2.34 & 0 & 0 \\
\hline$C 18: 1 \omega-9^{a}$ & 22.21 & 27.86 & 23.52 \\
\hline $\mathrm{C} 18: 1 \omega-7$ & 9.71 & 6.45 & 7.99 \\
\hline $\mathrm{C} 18: 2 \omega-6$ & 14.09 & 13.09 & 14.89 \\
\hline $\mathrm{C} 18: 3 \omega 6$ & 1.63 & 1.31 & 2.59 \\
\hline C18:3 $\omega-3$ & 0.93 & 0.8 & 0.58 \\
\hline C20:0 & 0.37 & 0.48 & 0.86 \\
\hline $\mathrm{C} 20: 1 \omega-9$ & 0.67 & 0.38 & 0.58 \\
\hline $\mathrm{C} 21: 0$ & 0 & 0 & 0 \\
\hline $\mathrm{C} 20: 4 \omega-6$ & 4.26 & 3.54 & 3.28 \\
\hline $\mathrm{C} 20: 5 \omega-3$ & 0 & 0 & 0 \\
\hline $\mathrm{C} 22: 5 \omega-3$ & 0 & 0 & 0 \\
\hline \multirow[t]{2}{*}{$\mathrm{C} 22: 6 \omega-3$} & 0 & 0 & 0 \\
\hline & 100 & 100 & 100 \\
\hline PUFAS & 20.9 & 18.7 & 21.3 \\
\hline MUFAS & 45 & 44.3 & 39.3 \\
\hline SFAS & 34.1 & 37 & 39.4 \\
\hline$\omega-3$ & 0.9 & 0.8 & 0.6 \\
\hline$\omega-6$ & 20 & 17.9 & 20.8 \\
\hline
\end{tabular}

\section{Acknowledgments}

To Universidad Nacional de Colombia for providing the funding help, through the Project "Incorporación de proteína microbiana proveniente de Biofloc y su 
efecto sobre la calidad organoléptica y nutricional de los filetes de cachama blanca Piaractus brachypomus" (code 18779); and to company Acuicultura y Asesoría ASYA SAS for the supply of pirapitinga juveniles.

\section{References}

ACUÑA REYES, M.J. Peces de cultivo, composición, comparación con carnes de consumo habitual. Ventajas del consumo de pescados. Diaeta, v.31, p.26-30, 2013.

AQUERRETA, Y.; ASTIASARÁN, I.; BELLO, J. Use of exogenous enzymes to elaborate the Roman fish sauce 'garum'. Journal of the Science of Food Agriculture, v.82, p.107-112, 2001. DOI: https://doi.org/10.1002/jsfa.1013.

AVNIMELECH, Y. Biofloc technology: a practical guide book. Baton Rouge: The World Aquaculture Society, 2009.

AZIM, M.E.; LITTLE, D.C. The biofloc technology (BFT) in indoor tanks: water quality, biofloc composition, and growth and welfare of Nile tilapia (Oreochromis niloticus). Aquaculture, v.283, p.29-35, 2008. DOI: https://doi.org/10.1016/j. aquaculture.2008.06.036.

BARRERO, M.; PAREDES, A.; ROMERO, O.; POLEO, G.A. Proximate composition and flesh quality of red bellied pacu, Piaractus brachypomus, cultured in two different closed systems. Agronomía Tropical, v.30, p.263-268, 2012.

BISWAS, A.; ARAKI, H.; SAKATA, T.; NAKAMORI, T.; KATO, K.; TAKII, K. Fish meal replacement by soy protein from soymilk in the diets of red sea bream (Pagrus major). Aquaculture Nutrition, v.23, p.1379-1389, 2017. DOI: https://doi.org/10.1111/anu.12513.

CARDONA, E.; LORGEOUX, B.; CHIM, L.; GOGUENHEIM, J.; LE DELLIOU, H.; CAHU, C. Biofloc contribution to antioxidant defence status, lipid nutrition and reproductive performance of broodstock of the shrimp Litopenaeus stylirostris: consequences for the quality of eggs and larvae. Aquaculture, v.452, p.252-262, 2016. DOI: https://doi.org/10.1016/j.aquaculture.2015.08.003.

CASTRO GONZÁLEZ, M.I.; MAAFS RODRÍGUEZ, A.G.; GALINDO GÓMEZ, C. Perfil de ácidos grasos de diversas especies de pescados consumidos en México. Revista de Biología Tropical, v.61, p.1981-1998, 2013. DOI: https://doi.org/10.15517/ rbt.v61i4.12875.

CASTRO, L.F.; PINTO, R.C.C.; NUNES, A.J.P. Nutrient value and contribution of microbial floc to the growth performance of juvenile shrimp, Litopenaeus vannamei, fed fatty acid and amino acid-restrained diets under a zero-water exchange intensive system. Aquaculture, v.531, art.735789, 2021. DOI: https://doi.org/10.1016/j.aquaculture.2020.735789.

CÉSPEDES ZAMBRANO, C.; LÓPEZ VARGAS, J. Caracterización proximal y perfil de ácidos grasos de la cachama blanca (Piaractus brachypomus). In: ENCUENTRO NACIONAL DE INVESTIGACIÓN Y DESARROLLO, 2015, Colombia. Inclusión social y desarrollo humano. Bogotá: Universidad Nacional de Colombia, 2015. p.1-6.
CHAVERRA GARCÉS, S.C. Contribución del biofloc como fuente de carbono y nitrógeno para el crecimiento de juveniles de cachama blanca (Piaractus brachypomus). 2016. Tesis (Maestría) - Universidad Nacional de Colombia, Medellín.

CHAVERRA GARCÉS, S.C.; GARCÍA GONZÁLEZ, J.J.; PARDO CARRASCO, S.C. Efectos del biofloc sobre los parámetros de crecimiento de juveniles de cachama blanca Piaractus brachypomus. Revista CES Medicina Veterinaria y Zootecnia, v.12, p.170-180, 2017. DOI: https://doi.org/10.21615/ cesmvz.12.3.1.

CRUZ-CASALLAS, P.E.; MEDINA-ROBLES, V.M.; VELASCO-SANTAMARÍA, Y.M. Fish farming of native species in Colombia: current situation and perspectives. Aquaculture Research, v.42, p.823-831, 2011. DOI: https://doi.org/10.1111/ j.1365-2109.2011.02855.x.

CUNNIFF, P. (Ed). Official Methods of Analysis of AOAC International. $16^{\text {th }}$ ed. $3^{\text {rd }}$ rev. Gaithersburg: AOAC International, 1997. Official Method 994-12.

EMERENCIANO, M.; CUZON, G.; ARÉVALO, M.; GAXIOLA, G. Biofloc technology in intensive broodstock farming of the pink shrimp Farfantepenaeus duorarum: spawning performance, biochemical composition and fatty acid profile of eggs. Aquaculture Research, v.45, p.1713-1726, 2014. DOI: https://doi.org/10.1111/are.12117.

EMERENCIANO, M.G.C.; MARTINEZ-CÓRDOVA, L.R.; MARTÍNEZ-PORCHAS, M.; MIRANDA-BAEZA, A. Biofloc Technology (BFT): a tool for water quality management in aquaculture. In: TUTU, H. (Ed.). Water quality. [S.1.]: IntechOpen, 2017. p.91-109. DOI: https://doi.org/10.5772/66416.

FAO. Food and Agriculture Organization of the United Nations. El estado mundial de la pesca y la acuicultura 2020: la sostenidad en acción. Roma, 2020. DOI: https://doi.org/10.4060/ca9229es.

GARCÍA, O.; ACEVEDO, I.; RUÍZ, R.J. Proximate analysis and microbiological and sensory evaluation of hamburger patties elaborated with red-bellied pacu (Piaractus brachypomus) and textured soy (Glycine max). Revista Venezolana de Ciencia y Tecnología de Alimentos, v.4, p.219-236, 2013.

GREGORY, N.G.; WOTTON, S.B. Effect of slaughter on the spontaneous and evoked activity of the brain. British Poultry Science, v.27, p.195-205, 1986. DOI: https://doi.org/10.1080/00071668608416872.

HABIB, M.A.B.; PARVIN, M.; HUNTINGTON, T.C.; HASAN, M.R. A review on culture, production and use of spirulina as food for humans and feeds for domestic animals and fish. Rome: FAO, 2008. 33p. (FAO Fisheries and Aquaculture Circular $\mathrm{n}^{\mathrm{o}}$ 10340).

HARDY, R. Utilization of plant proteins in fish diets: effects of global demand and supplies of fishmeal. Aquaculture Research, v.41, p.770-776, 2010. Special issue. DOI: https://doi.org/10.1111/ j.1365-2109.2009.02349.x.

HARGREAVES, J.A. Biofloc production systems for aquaculture. Stoneville: SRAC, 2013. (SRAC Publication $\mathrm{n}^{\circ}$ 45034503). 
ISO. International Organization for Standardization. ISO 15214:1998: Microbiology of food and animal feeding stuffs: horizontal method for the enumeration of mesophilic lactic acid bacteria: colony-count technique at 30 degrees C. Geneva, 1998.

ISO. International Organization for Standardization. ISO 4121:2003: Sensory analysis: guidelines for the use of quantitative response scale. Geneva, 2003.

IZQUIERDO CÓRSER, P.; FERRARI, G.T.; BARBOZA DE MARTÍNEZ, Y.; MÁRQUES SALAS, E.; ALLARA CAGNASSO, M. Análisis proximal, perfil de ácidos grasos, aminoácidos esenciales y contenido de minerales en doce especies de pescado de importancia comercial en Venezuela. Archivos Latinoamericanos de Nutrición, v.50, p.187-194, 2000.

MARTÍNEZ-CÓRDOVA, L.R.; EMERENCIANO, M.; MIRANDA BAEZA, A.; MARTÍNEZ-PORCHAS, M. Microbial-based systems for aquaculture of fish and shrimp: an updated review. Reviews in Aquaculture, v.7, p.131-148, 2015. DOI: https://doi.org/10.1111/raq.12058.
NRC. National Research Council. Nutrient requirements of swine. $11^{\text {th }}$ rev. ed. Washington: National Academies Press, 2012. DOI: https://doi.org/10.17226/13298.

RESTREPO, T.I.; DÍAZ G., G.J.; PARDO C., S.C. Peces dulceacuícolas como alimento funcional: perfil de ácidos grasos en tilapia y bocachico criados en policultivo. Biotecnología en el Sector Agropecuario y Agroindustrial, v.10, p.44-53, 2012.

SUÁREZ MAHECHA, H.; PARDO CARRASCO, C.S.; CORTÉS RODRÍGUEZ, M. Calidad físico-química y atributos sensoriales de filetes sajados biopreservados de cachama, empacados al vacío bajo refrigeración. Revista Colombiana de Ciencias Pecuarias, v.21 p.330-339, 2008.

SWANSON, D.; BLOCK, R.; MOUSA, S.A. Omega-3 fatty acids EPA and DHA: health benefits throughout life. Advances in Nutrition, v.3, p.1-7, 2012. DOI: https://doi.org/10.3945/ an.111.000893.

VÁSQUEZ TORRES, W. Principios de nutrición aplicada al cultivo de peces. Villavicencio: Universidad de los Llanos, 2004. 